\title{
Sex and Gender Roles, Division of Labor in
}

\author{
KATHRYN ROBINSON \\ Australian National University, Australia
}

In response to the emergence of second-wave feminism in the 1970s, many anthropologists turned to the critical question of sex differences in the societies we study (e.g., see Reiter 1975; Rosaldo and Lamphere 1974) and the sexual division of labor emerged as a critical area of inquiry. Feminist anthropologists have taken up historical and comparative perspectives on the sexual division of labor as a fundamental step in understanding gendered power. Is the sexual division of tasks, found in some form everywhere, always linked to male power over women? Does the critical and specific role of women in biological reproduction account for the sexual division of labor and for women's subordination which was deemed a universal fact? Some form of sexual division of labor appeared to be a sociocultural universal. In the case of horticultural communities, for example, it is often men who are tasked with clearing the fields while women have responsibility for weeding. Ester Boserup (1970) noted that the introduction of the plow universally led to soil preparation becoming men's work.

At the same time as this emerging stream of feminist-inspired inquiry in anthropology, feminist theory turned to the comparative cross-cultural perspectives offered by anthropology to address the question of whether the oppression of women was indeed universal; whether "patriarchy" was a universal category (e.g., see Leacock 1981).

Hence the 1970s saw many detailed ethnographic studies of the relative contributions of men and women to noncapitalist economies. For example, in the case of hunter-gatherer societies, scholars were keen to analyze the relative contribution of gathering activities, most commonly the principal tasks of women, to the total diets in these groups. In some cases it was argued that women's collection of vegetable products and hunting of small animals made a greater contribution to the diet than men's hunting. These studies also analyzed the ways in which the division of labor in production related to control of resources, and hence power, in society. Some feminist scholars argued that in the economic organization of hunter-gatherer societies, the sexual division of labor expressed egalitarian relations between men and women, arguing that male domination ("patriarchy") is not universal but a product of history.

Is the sexual division of tasks sufficient to explain the relative power of men and women? For example, in the New Guinea Highlands, women have the task of producing pigs that are used by men in exchange-but there has been a debate about the extent to which women are involved in the politics of pig and other forms of exchange, linked

The International Encyclopedia of Anthropology. Edited by Hilary Callan. (c) 2018 John Wiley \& Sons, Ltd. Published 2018 by John Wiley \& Sons, Ltd. DOI: $10.1002 / 9781118924396$.wbiea2208 
to the question of whether the sexual division of labor axiomatically produces male domination in all aspects of life.

Scholars have focused not only on the division of labor (tasks) in production but also how these related to division of labor in the "private" or "domestic" sphere. The primary responsibility of women for childcare and domestic organization in most societies emerges as a critical aspect of the sexual division of labor. The allocation of childbearing and the tasks of social reproduction to women were apparently universal. This led to questions of whether the biological bases of reproduction were also the basis of the sexual division of labor, and hence gender inequality. For some analysts, the identification of women with reproduction and the domestic was a primary cause of their lack of social power. This conclusion did not sit well with feminist scholars committed to understanding sex differences in historical and cross-cultural comparison in order to better struggle for gender equality.

The question becomes: How does sexual division of labor in both productive and reproductive spheres relate to the overall exercise of gendered power in society? In the case of capitalist societies, or capitalist sectors of developing societies, attention has focused on women's workplace participation in comparison to men: the sex segmentation of the workforce; the domination by men of the most highly paid jobs and in managerial positions; and the fact that women's wages are lower overall than those of men (now called the "gender pay gap"). For some Marxist analysis, the division of labor that relegated women to the domestic sphere is fundamental to the organization of capitalism. Women's unpaid domestic work underpins the ability of the capitalist system to extract surplus value from its workforce because the unpaid labor of women contributes to social reproduction/the reproduction of labor power, most notably in working-class families on low wages. The demand by labor unions for men to be paid a "family wage" was singled out as also contributing to the subordination of women.

During the 1970s, many anthropologists began to turn their attention to the impact of the incorporation of the small-scale (noncapitalist) societies, which had been the main focus of the discipline, into the global economy in which the capitalist market is dominant. The transformation of the sexual division of labor in ways that disadvantaged, even disempowered, women was analyzed as a critical aspect of the process whereby capitalist economic forms came to dominate those societies (Sacks, Warren, and Bourque 1991). An early hallmark work was Boserup's Women's Role in Economic Development (1970) in which she identified the negative effects of capitalist development on the sexual division of labor, to the detriment of women. This analysis went against the unreflected assumptions of development agencies at the time that "modernization" (the term used to describe the incorporation of noncapitalist societies into a global system in which capitalism is dominant) would positively transform women's social roles. The romanticized evolutionary story of modernization theory that underpinned much planned development axiomatically saw the position of women and the characteristic sexual division of labor in modern capitalist societies as the pinnacle of an inexorable process of economic and social transformation.

Under conditions of colonial rule, and also in many newly independent nations, the sexual division of labor was transformed, for example, by the selective recruitment of men (often as migrant laborers) in mines and on plantations, leaving women to 
manage all tasks in production (and reproduction) on their own, as well as by economic development practices that presumed male farmers and male heads of households and denied women farmers access to new crops, technologies, and know-how (Boserup 1970). Global markets created demand for women's handicrafts but when the work was carried out by "housewives" in the home it was not seen as production but as an aspect of domestic work (Mies 1982). A further transformation of the sexual division of labor on a world scale occurred with the expansion of global market factories into the developing world, which began in the late 1970s. Light manufacturing in the electronics, textiles, and footwear industries expanded into the so-called Third World on the back of technological innovations like wide-bodied jets which enabled the establishment of global production lines (Elson and Pearson 1981). Young women were selectively employed for these jobs, in clothing, textiles, and electronics, on the assumption they were better suited to the particular tasks. Elson and Pearson linked this to skills the young women brought to the "unskilled" jobs from the gender-specific tasks in their home communities and villages (sewing and weaving) that meant they developed these industrial skills more quickly than men. It was also assumed that factories preferred these young women as they were presumed to be more docile and biddable. In some places, they still lived at home and so family economies subsidized the reproduction of labor power (Sacks, Warren, and Bourque 1991; Wolf 1994).

In more recent years, there has been further transformation in the sexual division of labor on a world scale as a result of the rapid expansion in international migration associated with globalization and the increasing feminization of these labor flows. The global economy is opening up increasing numbers of positions for women in a globally sex-segmented workforce, mainly in sex-stereotyped service and caring occupations. In many parts of the world, these changes are a consequence of the demands of the capitalist labor market where low-paid occupational niches in caring professions are opening up for women rather than men. The expansion of these jobs is based on unreflected assumptions about women's capacity as carers.

Women are on the move, now accounting for about 50 percent of global migrants, many of them mothers and wives leaving behind husbands to take care of domestic tasks while they perform domestic labor or provide care for the elderly in wealthy households, often two-career households, in another country (Pareñas 2008). This sexual division of labor on a global scale, where women are propelled into waged work as international migrants, is a fundamental aspect of contemporary global capitalism.

While these migrant women are performing stereotyped "caring" work linked to their identification with reproduction, the customary sexual division of tasks in production (which tends to favor men) and the domestic sphere of social and biological reproduction (which has tended to be identified with the labor of women) is under transformation in many parts of the world. Women have been clamoring at the door to take on tasks which have been closed to them, including better-paid and more powerful jobs, partly as a consequence of structural changes that were a consequence of second-wave feminism (equal pay, antidiscrimination legislation, gender quotas). However, they are also entering "heavy, dirty" occupations, such as mining, that were previously closed to them. 
The changes in the sexual division of labor in production have been accompanied by changes in the division of labor in the domestic or private sphere. In developing countries, women's outward migration has often left men taking more responsibility for domestic tasks (childcare and housework, for instance), just as the emergence of the two-income, middle-class family in many industrial economies has been accompanied by reorganization of responsibilities for domestic tasks, indicated by, for example, men being able to claim paternity or parenting leave and housework not being the exclusive responsibility of women.

Whereas in the 1970s it was difficult to think about the division of labor by sex without becoming enmeshed in arguments about biology, debates today that draw attention to inequalities in the division of tasks are more likely to be discussed as an outcome of "the anthropology of gender to denote our concern with both sexes and their culturally and temporally varying relations" (Sacks, Warren, and Bourque 1991, 1) and the complex interaction of gender relations and the exercise of power.

SEE ALSO: Bride Service; Class; Division of Labor; Domestic Mode of Production; Domestic/Public Distinction; Economy, Feminist Approaches to; Family; Feminism, First-, Second-, and Third-Wave; Food-Sharing Models; Gender and Economics; Gender, Marxist Theories of; Gender and Migration; Home; Household; Hunter-Gatherer Models in Human Evolution; Labor, Employment, and Work; Mead, Margaret (1901-78); Mode of Production; Modernization Theories of Development; Patriarchy and Male Dominance; Power, Anthropological Approaches to; Sex and Gender Roles, Critiques of; Sexuality; Work

\section{REFERENCES AND FURTHER READING}

Boserup, Ester. 1970. Women's Role in Economic Development. London: George Allen \& Unwin. Elson, Diane, and Ruth Pearson. 1981. "The Subordination of Women and the Internationalization of Factory Production.” In Of Marriage and the Market: Women's Subordination in International Perspective, edited by Kate Young, Carol Wolkowitz, and Roslyn McCullagh, 144-66. London: CSE Books.

Leacock, Eleanor Burke, ed. 1981. Myths of Male Dominance: Collected Articles on Women Cross-culturally. New York: Monthly Review Press.

Mies, Maria. 1982. The Lace Makers of Narsapur. London: Zed Books.

Pareñas, Rhacel Salazar. 2008. The Force of Domesticity: Filipina Migrants and Globalization. New York: New York University Press.

Reiter, Rayna R., ed. 1975. Toward An Anthropology of Women. New York: Monthly Review Press.

Rosaldo, Michelle Zimbalist, and Louise Lamphere, eds. 1974. Woman, Culture and Society. Stanford: Stanford University Press.

Sacks, Karen, Kaye B. Warren, and Susan C. Bourque. 1991. "Women, Technology and International Development Ideologies: Analyzing Feminist Voices." In Gender at the Crossroads of Knowledge: Feminist Anthropology in the Post-modern Era, edited by Micaela di Leonardo, 278-310. Berkeley: University of California Press.

Wolf, Diane L. 1994. Factory Daughters: Gender, Household Dynamics, and Rural Industrialization in Java. Berkeley: University of California Press. 